\title{
Expression Profiling of Resistance Gene Analogs from French Bean (Phaseolus vulgaris L.) for the Manifestation of Rust (Uromyces phaseoli L.)
}

\author{
B. Divya*, B. Fakrudin and V. Devappa
}

College of Horticulture, Bengaluru, University of Horticulutural Sciences, Bagalkot, India
*Corresponding author

\begin{tabular}{|c|}
\hline Keywords \\
\hline $\begin{array}{l}\text { French bean, RGAs, } \\
\text { Arka Anoop, Arka } \\
\text { Sharath, Rust and } \\
\text { Expression analysis }\end{array}$ \\
\hline Article Info \\
\hline $\begin{array}{l}\text { Accepted: } \\
15 \text { February } 2019 \\
\text { Available Online: } \\
10 \text { March } 2019\end{array}$ \\
\hline
\end{tabular}

The resistant french bean genotype Arka Anoop and susceptible genotype Arka Sharath were used for expression profiling of RGAs for the manifestation of rust. Leaf tissue was collected from both resistant and susceptible genotypes which were challenged with rust spores separately at $15 \mathrm{DAI}$ and $45 \mathrm{DAI}$ and synthesized cDNA. The expression level of selected 10 RGA genes of french bean was measured in both resistant and susceptible genotype rust inoculated leaf tissues separately at 15 DAI and 45 DAI. At 15 DAI, in case of pathogen challenged leaf of resistant genotypes, the 9 COHFBRGA genes (COHFBRGA1 to COHFBRGA38 except COHFBRGA2) were up-regulated with a fold change range of 0.79 to 169.01 and COHFBRGA2 was down regulated with a fold change of 0.79 . Whereas, at $30 \mathrm{DAI}$ in the resistant genotype, all RGA genes were up-regulated with a fold change range of 20.01 (COHFBRGA9) to 115.69 (COHFBRGA25). In case of susceptible genotype, 5 RGA genes with the fold change ranged between 1.59 and 11.10 (15 DAI) and 7 RGA genes with 0.10 (COHFBRGA38) to 19.29 (COHFBRGA9) were down-regulated. Highest fold expression was found at 15 DAI in resistance genotype by COHFBRGA26 and lowest noticed in susceptible genotype at 30 DAI by COHFBRGA38.

\section{Introduction}

French bean, Phaseolus vulgaris L. $(2 \mathrm{n}=22)$ is a member of the family Fabaceae. It is an important legume vegetable grown for its tender green pods either for fresh consumption or for processing as canned, frozen or freeze dried product. It is a nutritive vegetable which supplies protein $(1.8 \mathrm{~g})$, calcium (132 $\mathrm{mg})$, thiamin $(0.08 \mathrm{mg})$, riboflavin $(0.06 \mathrm{mg})$ and vitamin $\mathrm{C}(24 \mathrm{mg})$ per $100 \mathrm{~g}$ of edible pods. Its pods can be used to strengthen diuretic, flushing of toxins from the body and also infused in the treatment of diabetics (Prajapati, 2003).
It is native of new world, principally Central and South America (Kalpan, 1981) with small genome $633 \mathrm{Mbp}$ (Arumuganatham and Earle, 1991). It is originated from wild species Phaseolus aborigineus L. and domesticated in Mexico, Peru and Colombia about 8000 years ago. In world, french bean is grown over an area of 1.48 million ha with annual production of 17.65 million MT and the productivity of $11.95 \mathrm{t} / \mathrm{ha}$. In India, its cultivation is in 0.21 million ha with production of 0.58 million MT and productivity of $2.8 \mathrm{t} / \mathrm{ha}$ (Anon., 2015). 
Like any other crops, legume vegetables are also susceptible to various biotic and abiotic stresses. Among the biotic stresses, rust (Uromyces phaseoli L.) has become epidemic in bean growing areas and especially in locations where humid to moderately humid conditions, long dew periods and cool conditions prevail during the growing season of beans. $U$. phaseoli is an autoecious, macrocyclic, obligate parasite acts both on inter and intracellular tissue by inserting haustoria (Rangaswamy, 1975). The pathogen infects leaves, pods, petioles, rarely stems and branches. Initial symptoms appear usually on the lower surfaces as minute whitish slightly raised spots. These spots enlarge to form mature reddish brown pustules (Harter and Zaumeyer, 1941).

The yield loss due to rust ranges from 18 to 78 per cent (Mohan et al., 1993). This disease is more severe in tropics than in temperate region (Coyne and Schuster, 1975). Fungicides like chlorothalonil, dithiocarbamates, triazoles and carboxins (Liebenberg and Pretorius, 2010) are being used to control the disease. But, genetic resistance always has an edge over the other means of disease control as it is eco-friendly. Host plant resistance is very important because of high virulence and diversity of rust pathogen (Lopez et al., 2003).

Many defense responses are initiated by resistance gene/genes, providing a mechanism by which the plant can recognize a pathogen and execute a defense response against it. Plant resistance $(\mathrm{R})$ genes are thought to be one of the components of the genetic resistance mechanism in plants (Flor, 1956). Development of plant organs is determined by differential gene expression which can be regulated at different levels. Numerous $R$ genes and RGAs have now been cloned, determination of activity and specificity against a given pathogen for development of durable resistance is important in french bean and other crop species (Madsen et al., 2003). Advancement in technologies such as DNA sequencing methodologies, throughput platform DNA array, northern blotting, subtractive hybridization, real-time PCR etc. have tremendously increased our knowledge of transcriptomes. But, the advent of real-time PCR technology has significantly changed the field of measuring gene expression in both the animal and plant molecular biology research.

Real-time PCR is the technique of collecting data throughout the PCR process as it occurs, thus combining amplification and the detection into a single step. It has become one of the most widely used methods of gene quantitation because of its high sensitivity, good reproducibility and wide dynamic quantitation range. It is the most sensitive method for the detection and quantitation of gene expression levels, in particular for low abundant transcripts in tissues with low RNA concentrations, from limited tissue sample and for the elucidation of small changes in mRNA expression levels (Mackay et al., 2002). Keeping these in view, we conducted on expressional analysis of resistance gene analogs in response to rust disease manifestation in French bean.

\section{Materials and Methods}

\section{Plant material and growth condition}

French bean genotypes resistant (Arka Anoop) and susceptible (Arka Sharath) to rust were raised in pots containing a mixture of soil, sand and well decomposed Farm Yard Manure (FYM) in the ratio of 2:1:1. The filled pots were kept in polyhouse. The pot mixture was sterilized before use. In replicated trials one seed was sown in each pot. Rust spores were collected from infected plants in farmers filed and dissolved in water at $10^{3}$ concentration and spread on pots one month 
after sowing. Control pots were maintained without inoculation both in resistant and susceptible genotypes. Both from susceptible and resistant french bean genotypes the tissues were collected from leaf tissues. Under virulent pathogen challenging situations, tissues from different stages (15 and 30 days after post inoculation and till the completion of the disease infestation) targeting different stages of disease manifestation were collected both from challenged and control plant. The tissues were frozen with liquid nitrogen and stored at $-80^{\circ} \mathrm{C}$ for isolation of total RNA (Plate 1).

\section{RNA isolation and cDNA synthesis}

Total RNA was isolated from leaf tissues of Arka Anoop and Arka Sharath genotypes from both rust infected and non infected conditions using TRIzol reagent. and driver cDNAs were prepared from the total RNA of each treatment by using SuperScript ${ }^{\circledR}$ VILO $^{\mathrm{TM}}$ cDNA Synthesis Kit (Cat.no.11754050, Invitrogen) as per the manufacturer's protocol.

\section{Candidate-gene selection and primer design}

For 10 selected sequences of RGAs cloned in the our previous study the primer pairs were designed using Primer3Plus software and primers were synthesized by Eurofins Genomics India Pvt. Ltd. Bengaluru. A predicted melting temperature (Tm) of $60+2^{\circ} \mathrm{C}$, primer lengths of $20-24$ nucleotides, guanine-cytosine (GC) contents of 45-55 per cent and PCR amplicon length of 90-200 base pairs (bp) were adopted for designing the primer pairs. The specificity of primer pairs were reconfirmed by searching homology in NCBI, BLAST search. The list of candidate genes and their respective primer pairs are shown in Table 1. PCR amplification of RGAs was optimized for different components using gradient PCR by Eppendorf master cycles gradient. PCR reactions were performed for genotype in a total volume of $20 \mu \mathrm{l}$ containing $100 \mathrm{ng}$ of cDNA, $1 \times$ PCR buffer, $2.5 \mathrm{mM} \mathrm{MgCl} 2,0.2$ $\mathrm{mM}$ dNTPs, $0.1 \mu \mathrm{M}$ of each primer, and 2.5 units of $T a q$ polymerase (Invitrogen Life Technologies, Carlsbad, CA). Cycling conditions were initial denaturation at $95^{\circ} \mathrm{C}$ for $10 \mathrm{~min}$, followed by 40 amplification cycles $\left(95^{\circ} \mathrm{C}\right.$ for $15 \mathrm{~s}$, annealing temp ${ }^{\circ} \mathrm{C}$ for $20 \mathrm{~s}$, and $68^{\circ} \mathrm{C}$ for $20 \mathrm{~s}$ ) and a melting curve step at $95^{\circ} \mathrm{C}$ for $10 \mathrm{~min}$ before holding at $\left.4^{\circ} \mathrm{C}\right)$.

The master mix of different components of real-time PCR was prepared fresh to avoid handling errors. The reaction mixture of $10 \mu \mathrm{l}$ containing $1.0 \mathrm{ng}$ cDNA, $200 \mathrm{nM}$ of each gene specific primer and $5 \mu$ of $2 x$ SYBR green reagents (Cat.\#4368706, Ambion, USA) were used in the experiment. Individual components of reaction mixture were standardized for $10 \mu \mathrm{l}$ reaction volume. In our experiment we selected Arabidopsis thaliana housekeeping gene actin as an internal control (Caldana et al., 2007 and Czechowski et al., 2004).

The mathematical model delta-delta $\mathrm{Ct}$ method (Livak and Schmittgen, 2001) was used to determine relative expression ratio (fold change). In real-time PCR, fluorescence was recorded at each cycle to monitor the generation of amplified product. For proper calculation of initial target levels, differences in efficiency of amplification (E) must be taken into consideration. Even small differences in amplification efficiencies (E) will get added up making large apparent differences in mRNA levels. The absolute quantification requires a set up of standard curves from which PCR efficiency will be deduce; the disadvantages of standard curves are (i) the extra efforts and cost needed to set up additional samples (ii) Non matching E 
due to presence of inhibitors and serial dilutions. The relative quantification with PCR efficiency correction was adopted to calculate the fold change expression.

PCR efficiency of all the RGAs was obtained from the exponential phase of each individual amplification plot using the equation $(1+\mathrm{E})$ =10slope (Ramakers et al., 2003). The LinReg PCR (http://www.bioinfo @amc.uva.nl; subject: LinRegPCR) software based on the above equation proposed a linear regression on the log fluorescence per cycle number data as an assumption-free method was used to calculate starting concentrations of mRNA and PCR efficiencies for each sample. The log-linear part of the PCR data was determined for each sample by selecting a lower and an upper limit of a "window of linearity". Linear regression analyses was used to calculate the intercept and the slope, $\log$ (No) and $\log$ (eff.) respectively, from the straight line that fits best to the included data points. The individual PCR efficiency follows from the slope of the linear regression line (Eff $=10$ slope) and used as a quality check to exclude possible contained samples. To ensure unambiguous selection of data point within the "window of linearity", the lines consisting of at least 4 and not more than 6 data points with the highest R2 value (0.99) and slope close to the maximum slope were selected.

\section{Processing the raw fluorescence data}

Pre-requisite for LinReg PCR to achieve maximum PCR efficiency is background corrected fluorescence data points of each well. Raw fluorescence data was obtained from the Applied Biosystems stepone RTPCR and this background was due to residual fluorescence of the dye, differences in tube transparency, dust, noise of the electronics etc. In majority of cases, a variable background makes a near-linear contribution to the curves generated by the amplifier and it should be subtracted from the raw fluorescence without distorting the data considerably. For background correction, the baseline fluorescence data was collected from 3-15 cycles. The fluorescence increments (raw fluorescence -Yo) were normalized to reaction fluorescence background (Yo) for each sample reaction as below ( $\mathrm{Yu}$ et al., 2006).

\section{Normalized fluorescence $=$ raw fluorescence - Yo/ Yo}

The proposed method minimized the influence of the initial vertical background shift of reaction. The background corrected or normalized fluorescence data was used to calculate PCR efficiency by LinReg PCR software. The calculated PCR efficiency was used to derive fold expression of TFs gene using the following method:

$$
\text { Ratio }=\frac{(\mathrm{E} \text { target })^{-\Delta \mathrm{Ct}}}{(\mathrm{E} \text { control })^{-\Delta \mathrm{Ct}}}
$$

E target $=$ PCR efficiency of target gene in sample.

E control $=$ PCR efficiency of target gene in control.

$\Delta \mathrm{Ct}=(\mathrm{Ct}$ of target gene $-\mathrm{Ct}$ of reference gene).

\section{Results and Discussion}

Predicted features and functions of 10 cloned RGA genes were selected in this experiment for their expression analysis (Table 1). The total RNA from each treatment was treated with DNase I enzyme to eliminate traces of genomic DNA (Plate 2). Actual confirmation of complete degradation of genomic DNA in RNA preparation was done through PCR amplification using total RNA as template. There was no amplification from the total 
RNA preparation indicating absence of traces of genomic DNA as contamination (Plate 3 and 4). However, elimination of contaminating genomic DNA enzymatically is very important in gene expression analysis using qRT-PCR (Chini et al., 2007). Presence of genomic DNA/genetic copies of genes seriously alter the precision of expression quantitation of genes in target tissues.

Generally, 18S rRNA, EF-1, $\alpha$ actin, $\beta$ tubulin and ubiquitin (UBQ) genes are considered as good reference genes for any gene expression experiment (Caldana, 2007; Czechowski et al., 2004). The gene expression stability measure (M) was estimated to identify the most stable reference gene among actin (AC1), $\beta$-tubulin, 18S rRNA and elongation factor-1 through qRT-PCR in a set of 3 different cDNA samples corresponding to different interval of day after flowering i.e. 7 DAI, 15 DAI and 30 DAF tissues from french bean leaves inoculated with rust (where inoculated samples were collected from both resistant and susceptible genotypes at different intervals). The NormFinder software which uses model-based variance estimation approach was used; the $M$ value should be $<1.5$. The $\mathrm{M}$ value, $0.298,0.311$ and 0.326 for actin (AC1), 18S rRNA and $\beta$-tubulin respectively, based on $\mathrm{M}$ value actin $(A C 1)$ gene was selected as endogenous reference gene for rest of qRT-PCR experiments. In several instances these gene has been tested and used as reference genes in qRT-PCR experiments, and the $M$ values of these reports are within the range of present experimental results (Claus et al., 2004; Ruth et al., 2008; Kakar et al., 2008). It is the most stable combination indicating the absence of significant differences in the expression levels of reference genes in varied experimental conditions. In several instances of plant gene expression analysis by qRT-PCR these genes with similar combination have been adopted (Marino et al., 2003).
PCR efficiency correction was used to calculate the fold change expression in the relative quantification of gene expression. The PCR efficiency of selected genes was calculated from the exponential phase of individual amplification plot using the equation $(1+\mathrm{E})=10^{\text {slope }}$ (Ramakers et al., 2003). Subsequently, the average PCR efficiencies were computed for each individual primer pairs across all analyzed samples. The range of PCR efficiency determined was in consistent with the results reported by Kakar et al., (2008), Caldana et al., (2007) and Czechowski et al., (2004). Further, PCR efficiency was used to calculate final fold change of selected genes. The deltadelta $\mathrm{Ct}$ method (Livak and Schmittgen, 2001) was used to determine relative expression ratio of 27 genes (fold change). The delta-delta mathematical model of determining fold changes in the expression of genes is widely adopted in qRT-PCR (Czechowski et al., 2004; Buchanan et al., 2005; Caldana et al., 2007; Yang et al., 2010). In this method an amplification efficiency of each gene specific primer pairs from the log slope of fluorescence versus cycle number in the exponential phase and the same is used to calculate fold expression using the delta-delta Ct method. Similarly, Caldana et al., (2007) and Yang et al., (2010) used delta-delta Ct method to calculate relative fold change in rice and common bean respectively.

The technical precision of qRT-PCR was assessed by performing replicated measurements in separate PCR runs. The same pool of cDNA to account the precision in technique employed and two different pools of cDNA obtained independently from two different batches of total RNA under same condition to test precision of biological responses of plant to different day after inoculation were used. Precision, as reflected by the correlation coefficient, was high in both cases; technical and biological replicates 
recorded correlation coefficient values greater than 0.970 and 0.968 in different day after inoculation tissues indicating high precision of technical and biological treatments and response of french bean tissues (Figure 2a and 2b). A similar strategy to monitor the technical and biological precision of experiment was adopted by Czechowski et al., (2004) in Arabidopsis thaliana and by Kakar et al., (2008) in Medicago.

Table.1 Specific primer pair sequences of french bean RGAs analyzed in response to $M Y M V$ disease manifestation using qRT-PCR

\begin{tabular}{|c|c|c|c|c|c|c|}
\hline $\begin{array}{l}\text { Sl. } \\
\text { no. }\end{array}$ & Primer name & Primer sequence (5'-3') & $\begin{array}{l}\text { Length } \\
\text { (bp) }\end{array}$ & $\begin{array}{l}\mathbf{T m} \\
\left({ }^{\circ} \mathbf{C}\right)\end{array}$ & GC (\%) & $\begin{array}{l}\text { Product } \\
\text { size (bp) }\end{array}$ \\
\hline \multirow[t]{2}{*}{1} & COHFBRGA1_F & ATGCAGGCCTCTGCAGTC & 18 & 60.1 & 61.1 & \multirow[t]{2}{*}{163} \\
\hline & COHFBRGA1_R & ACCTCGCGAATGCATCTA & 18 & 57.9 & 50.0 & \\
\hline \multirow[t]{2}{*}{2} & COHFBRGA2_F & GAGTCAGTGAGCGAGGAAGC & 20 & 60.3 & 60.0 & \multirow[t]{2}{*}{263} \\
\hline & COHFBRGA2_R & AGCTTGGCGTAATCATGGTC & 20 & 60.1 & 50.0 & \\
\hline \multirow[t]{2}{*}{3} & COHFBRGA3_F & ACCATGATTACGCCAAGCTC & 20 & 60.1 & 50.0 & \multirow[t]{2}{*}{245} \\
\hline & COHFBRGA3_R & CAGCAGCAGAAGCACAACTC & 20 & 59.9 & 55.0 & \\
\hline \multirow[t]{2}{*}{4} & COHFBRGA4_F & CAGGCGACGTCGAGATCTAT & 20 & 60.4 & 55.0 & \multirow[t]{2}{*}{162} \\
\hline & COHFBRGA4_R & GTGCTGCAAGGCGATTAAGT & 20 & 60.4 & 50.0 & \\
\hline \multirow[t]{2}{*}{5} & COHFBRGA9_F & GAGTCAGTGAGCGAGGAAGC & 20 & 60.3 & 60.0 & \multirow[t]{2}{*}{263} \\
\hline & COHFBRGA9_R & AGCTTGGCGTAATCATGGTC & 20 & 60.1 & 50.0 & \\
\hline \multirow[t]{2}{*}{6} & COHFBRGA25_F & GTCGAGGAAATGGCCAAA & 18 & 59.6 & 50.0 & \multirow[t]{2}{*}{154} \\
\hline & COHFBRGA25_R & CACAGTCCCAGCAGCAGA & 18 & 59.7 & 61.1 & \\
\hline \multirow[t]{2}{*}{7} & COHFBRGA26_F & CGAGGAAATGGCCAAAAGTA & 20 & 60.1 & 45.0 & \multirow[t]{2}{*}{179} \\
\hline & COHFBRGA26_R & CGCTGGAAGAAGAGAAATGC & 20 & 60.1 & 50.0 & \\
\hline \multirow[t]{2}{*}{8} & COHFBRGA27_F & CGAGGAAATGGCCAAAAGTA & 20 & 60.1 & 45.0 & \multirow[t]{2}{*}{179} \\
\hline & COHFBRGA27_R & CGCTGGAAGAAGAGAAATGC & 20 & 60.1 & 50.0 & \\
\hline \multirow[t]{2}{*}{9} & COHFBRGA32_F & CTCCGCCTAGGAGTGAGTTG & 20 & 60.0 & 60.0 & \multirow[t]{2}{*}{217} \\
\hline & COHFBRGA32_R & GCCGTGCCTAAAGACTGAAC & 20 & 59.9 & 55.0 & \\
\hline \multirow[t]{2}{*}{10} & COHFBRGA38_F & AACGTCGTGACTGGGAAAAC & 20 & 60.0 & 50.0 & \multirow[t]{2}{*}{145} \\
\hline & COHFBRGA38_R & AATTTCCATTCGCCATTCAG & 20 & 59.9 & 40.0 & \\
\hline
\end{tabular}


Table.2 Relative change in the expression pattern of selected R genes found in rust inoculated leaf tissue of different genotypes of french bean

\begin{tabular}{|c|c|c|c|c|c|c|c|c|c|c|c|c|c|c|c|c|c|c|c|c|c|}
\hline \multirow[t]{2}{*}{ Sl. No. } & \multirow[t]{2}{*}{ R gene } & \multicolumn{4}{|c|}{$\begin{array}{c}\text { Normalize } \Delta \mathrm{Ct} \text { values } \\
\text { (control) }\end{array}$} & \multicolumn{4}{|c|}{ Normalize $\Delta \mathrm{Ct}$ values } & \multicolumn{4}{|c|}{ Fold expression } & \multicolumn{4}{|c|}{ Log10 ratio } & \multicolumn{4}{|c|}{ Cal. $t$ value } \\
\hline & & $\begin{array}{c}15 \\
\text { DAIR }\end{array}$ & $\begin{array}{c}15 \\
\text { DAIS }\end{array}$ & $\begin{array}{c}30 \\
\text { DAIR }\end{array}$ & $\begin{array}{c}30 \\
\text { DAIS }\end{array}$ & $\begin{array}{c}15 \\
\text { DAIR }\end{array}$ & $\begin{array}{c}15 \\
\text { DAIS }\end{array}$ & $\begin{array}{c}30 \\
\text { DAIR }\end{array}$ & $\begin{array}{c}30 \\
\text { DAIS }\end{array}$ & $\begin{array}{c}15 \\
\text { DAIR }\end{array}$ & $\begin{array}{c}15 \\
\text { DAIS }\end{array}$ & $\begin{array}{c}30 \\
\text { DAIR }\end{array}$ & $\begin{array}{c}30 \\
\text { DAIS }\end{array}$ & $\begin{array}{c}15 \\
\text { DAIR }\end{array}$ & $\begin{array}{c}15 \\
\text { DAIS }\end{array}$ & $\begin{array}{c}30 \\
\text { DAIR }\end{array}$ & $\begin{array}{c}30 \\
\text { DAIS }\end{array}$ & $\begin{array}{c}15 \\
\text { DAIR }\end{array}$ & 15 DAIS & $\begin{array}{c}30 \\
\text { DAIR }\end{array}$ & $\begin{array}{c}30 \\
\text { DAIS }\end{array}$ \\
\hline 2 & RGA2 & -1.07 & 0.91 & -0.11 & -1.40 & -1.07 & 1.59 & -0.12 & 1.46 & 0.79 & 1.59 & 44.85 & 0.68 & -0.10 & -0.21 & 5.65 & -0.17 & 0.20 & 0.32 & 0.32 & 0.82 \\
\hline 3 & RGA3 & -0.10 & 4.67 & 3.84 & 1.00 & -0.10 & 6.22 & 3.84 & 3.86 & 56.90 & 6.22 & 57.88 & 1.75 & 1.76 & -0.47 & 4.76 & 0.24 & 0.20 & 0.33 & 0.33 & 0.82 \\
\hline 4 & RGA4 & 6.66 & 11.85 & 8.68 & 9.84 & 6.66 & 9.77 & 8.67 & 12.70 & 1.42 & 9.77 & 40.60 & 0.56 & 0.15 & 0.62 & 3.61 & -0.26 & 0.32 & 0.33 & 0.33 & 0.98 \\
\hline 5 & RGA5 & 0.80 & 11.85 & 2.08 & 1.35 & 0.80 & 3.90 & 2.08 & 4.21 & 12.98 & 3.90 & 78.49 & 19.29 & 1.11 & 2.39 & 5.89 & 2.30 & 0.30 & 0.34 & 0.34 & 0.98 \\
\hline 6 & RGA6 & 0.98 & 2.67 & 2.52 & 0.27 & 0.98 & 3.98 & 2.52 & 3.13 & 1.45 & 3.98 & 115.69 & 0.72 & 0.16 & -0.40 & 6.06 & -0.14 & 0.34 & 0.35 & 0.35 & 0.30 \\
\hline 7 & RGA7 & 4.60 & -4.16 & 8.40 & 3.82 & 4.59 & 11.07 & 8.40 & 6.68 & 169.01 & 11.07 & 39.30 & 0.00 & 2.23 & -4.58 & 4.59 & -3.26 & 0.35 & 0.37 & 0.37 & 0.32 \\
\hline 8 & RGA8 & -8.15 & -3.01 & -4.34 & -4.41 & -8.15 & -2.97 & -4.34 & -1.55 & 1.04 & -2.97 & 53.77 & 0.36 & 0.02 & -0.01 & 8.73 & -0.44 & 0.32 & 0.40 & 0.40 & 0.36 \\
\hline 9 & RGA9 & -0.01 & 0.16 & 1.35 & 0.96 & -0.01 & 2.87 & 1.35 & 3.82 & 1.69 & 2.87 & 20.01 & 0.08 & 0.23 & -0.82 & 7.32 & -1.10 & 0.57 & 0.40 & 0.40 & 0.45 \\
\hline 10 & RGA10 & 3.17 & 5.79 & 5.03 & 6.24 & 3.17 & 11.10 & 5.02 & 9.10 & 22.04 & 11.10 & 32.55 & 0.10 & 1.34 & -1.60 & 6.51 & -1.00 & 0.35 & 0.37 & 0.46 & 0.47 \\
\hline
\end{tabular}


Fig.1 Relative change in the expression pattern of selected RGA genes found in rust manifested leaf tissue at 15 and 30 days after inoculation of resistant and susceptible genotypes in french bean

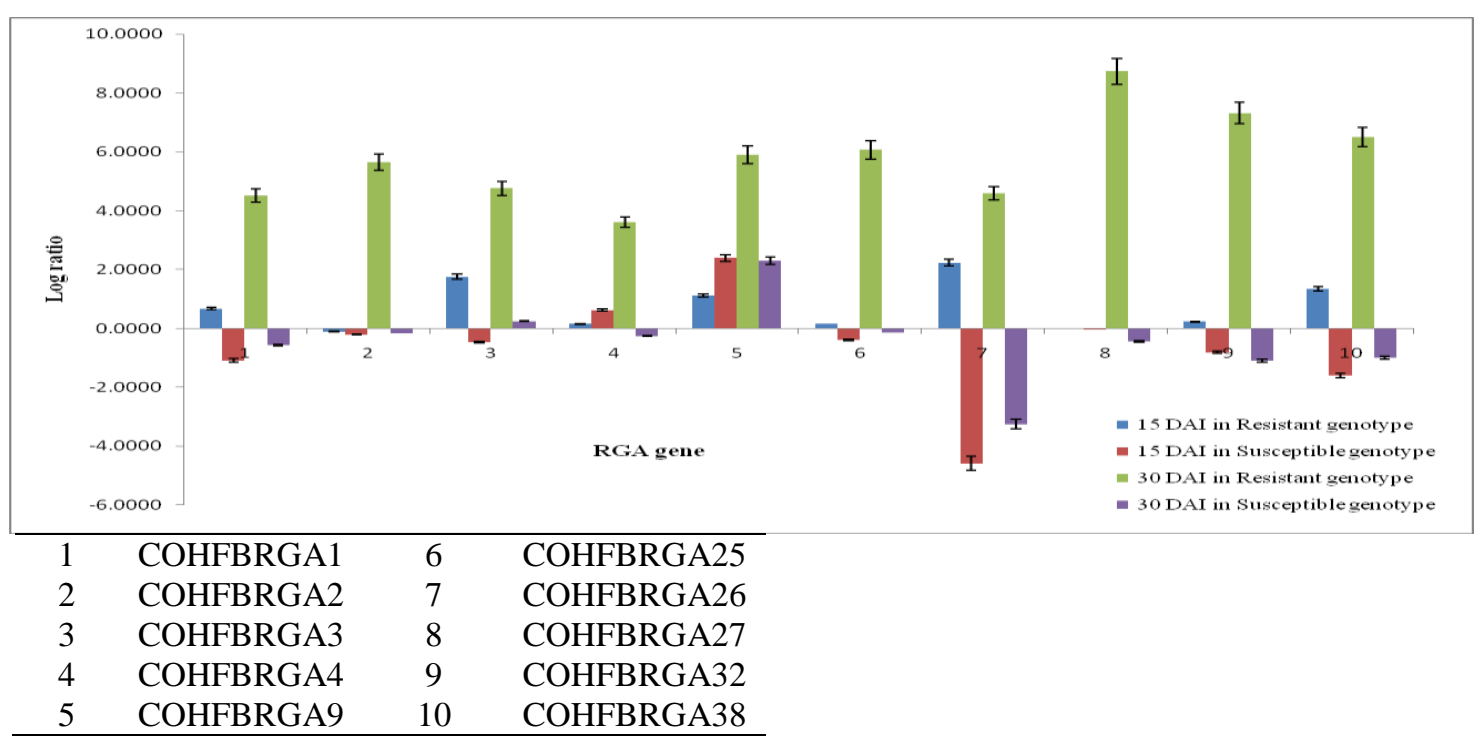

Fig.2a Technical precision of real time PCR reflected as correlation coefficient between the duplicate measurements of cDNA levels of genes from the same reverse transcription reaction (biological replicates)

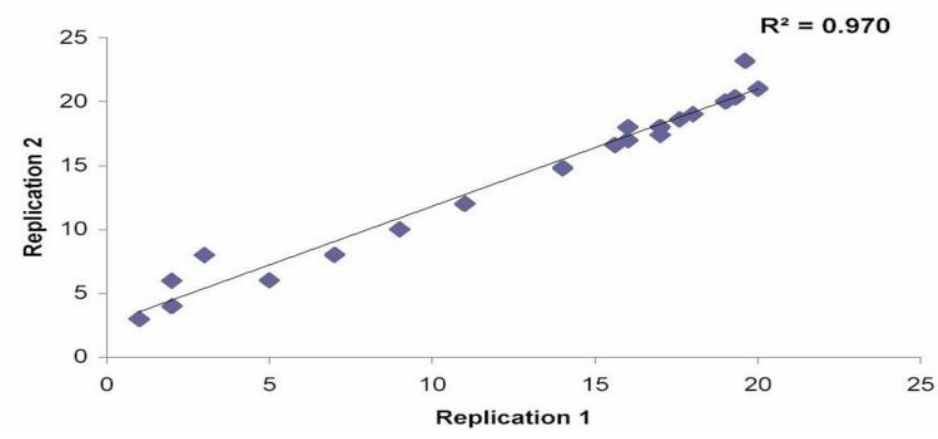

Fig.2b Technical precision of real time PCR reflected as correlation coefficient between the duplicate measurements of cDNA levels of genes from the same reverse transcription reaction (technical replicates)

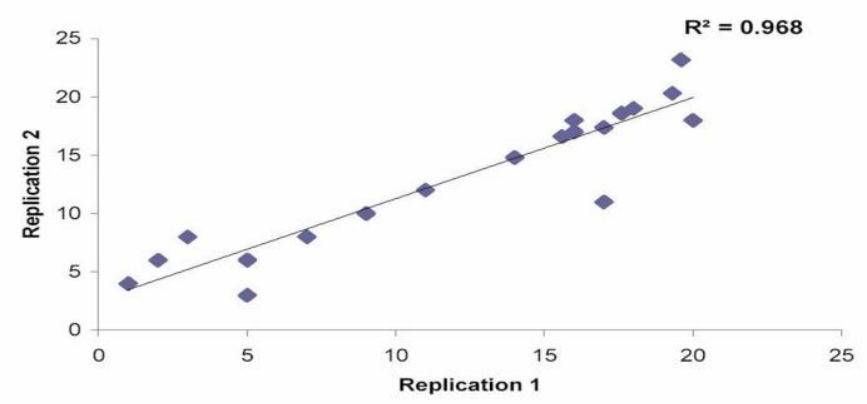




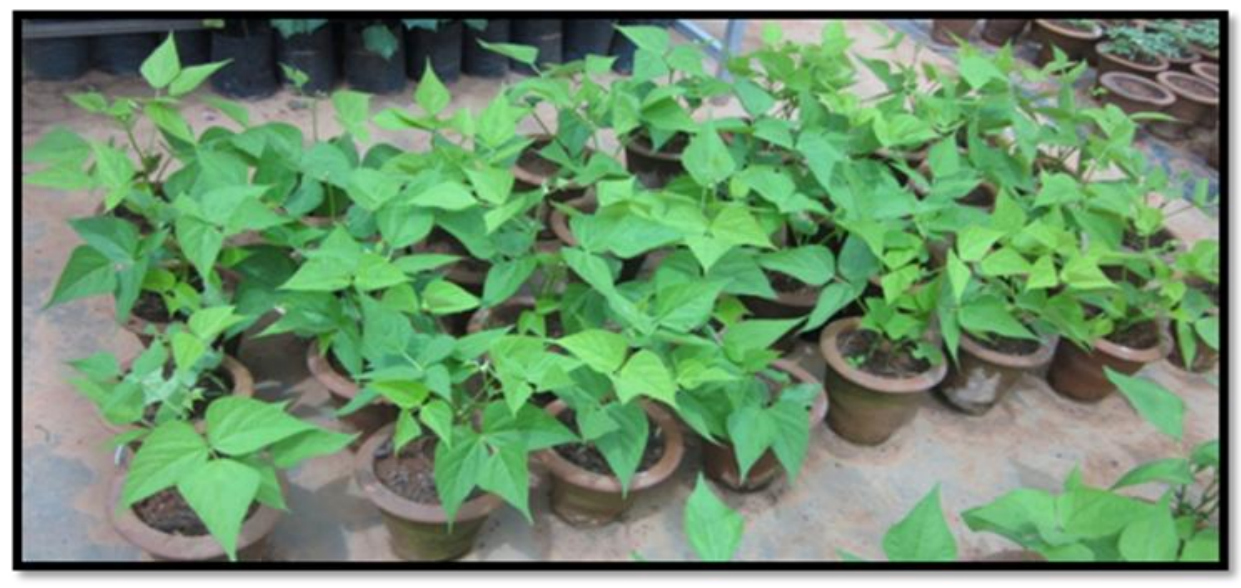

Plate 1a: With out disease inoculation of rust

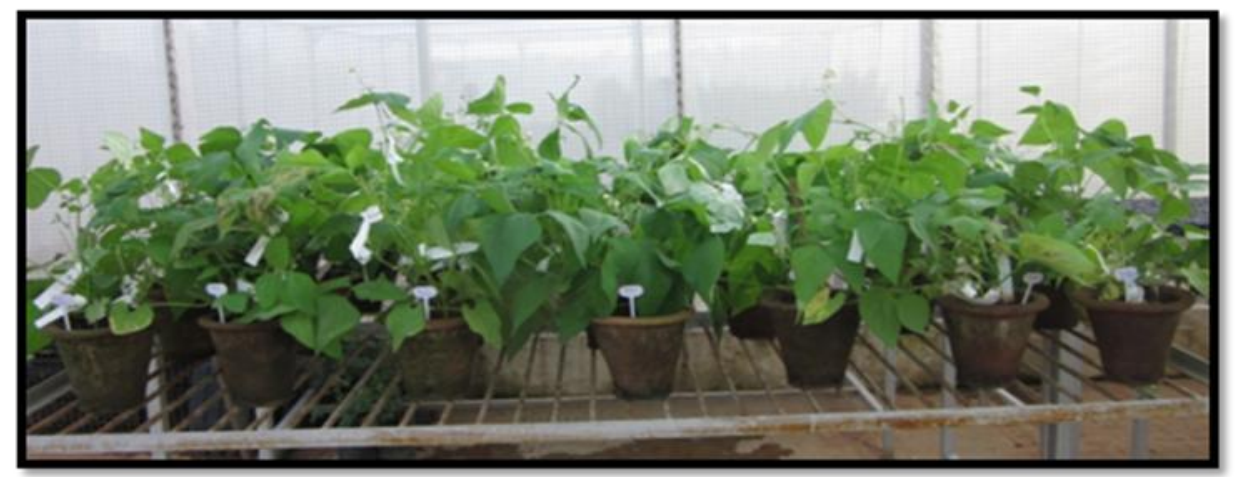

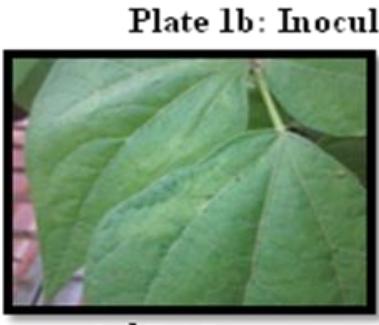

$2^{\text {nd }} \mathrm{DAI}$

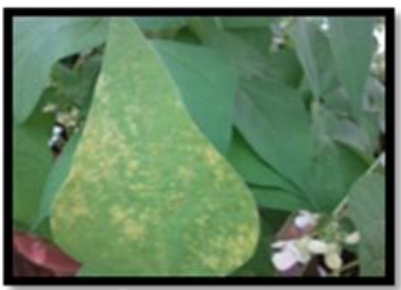

$15^{\text {th }}$ DAI

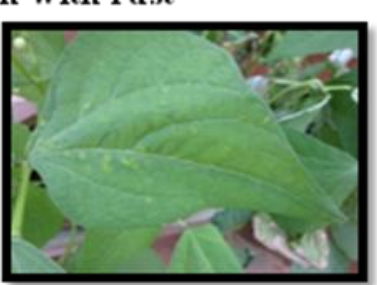

$7^{\text {th }}$ DAI

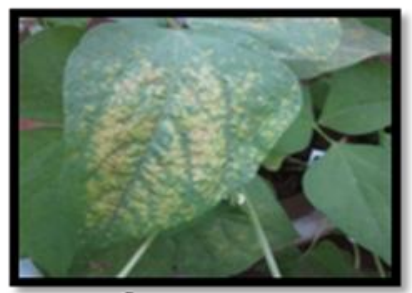

$30^{\text {th }}$ DAI

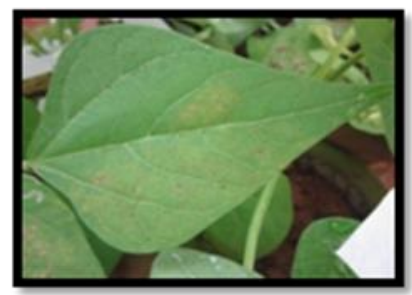

$10^{\text {th }}$ DAI

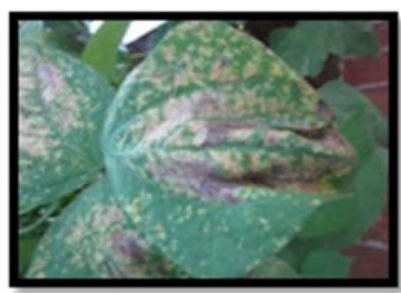

$4^{\text {th }}$ DAI

Plate $1 \mathrm{c}$ : Rust symptoms at disease development at differ ent stages

Plate 1: Gener al view of pot culture for rust infected tissues collection 


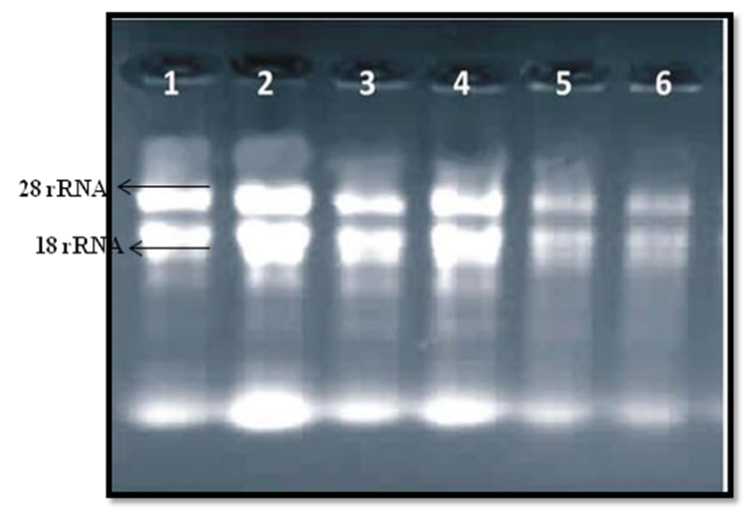

1-3-TOTAL RNA samples of rust infected leaf 4-6-TOTAL RNA samples of MYMV infected leaf

Plate 2: Confirmation of integrity and quality of total RNA on formald ehyde denaturing agarose gel

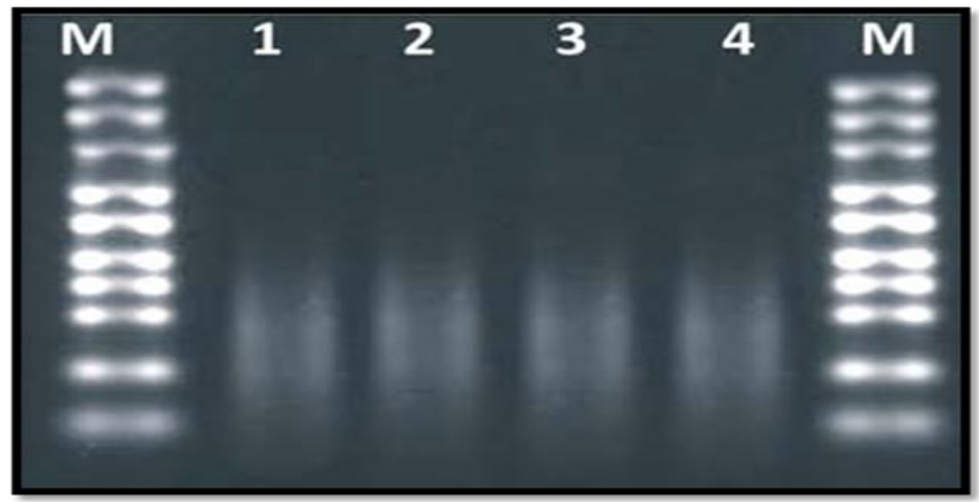

M: 1000 bp ladder

Plate 3: cDNA from different stage of rust infected leaf sample on 1.2 per cent agarose
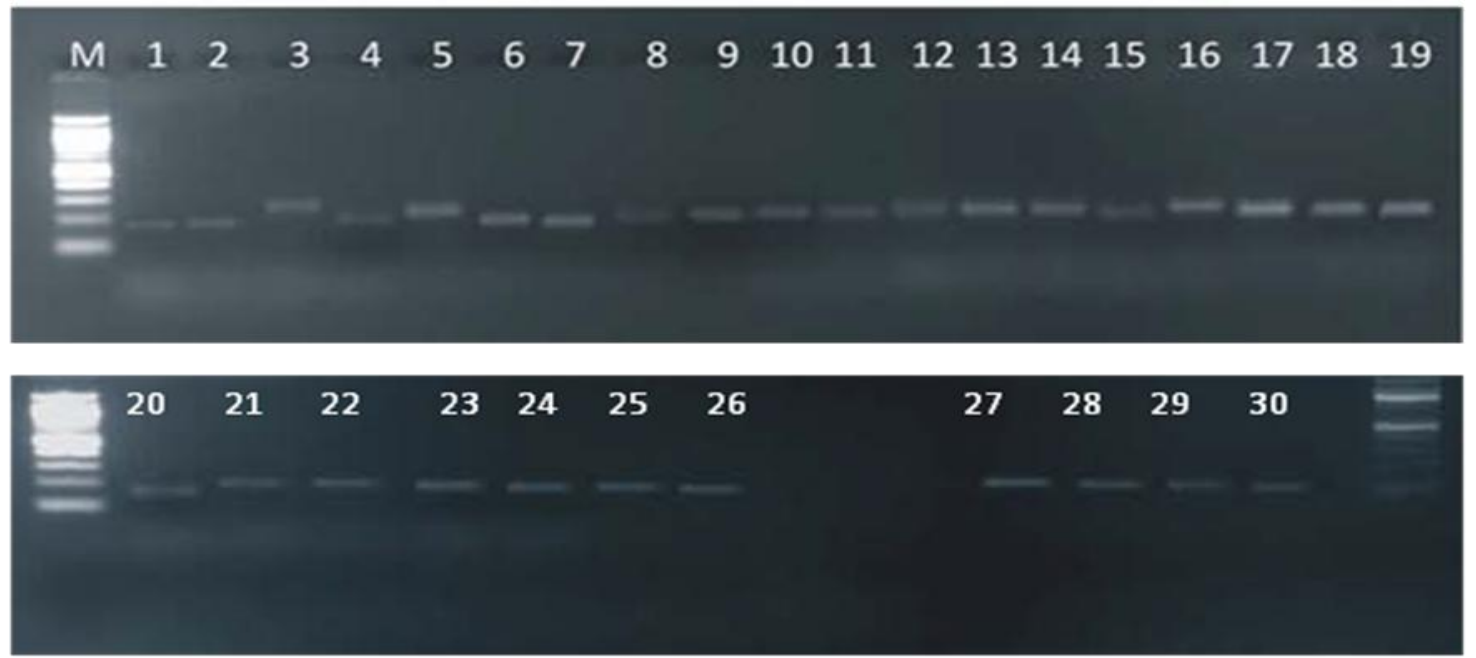

Plate 4: PCR confirmation with DNA of all predicted genes on $2.5 \%$ agarose gel 
Melting curve analyses was performed for all PCR products to confirm the occurrence of specific amplification peaks and the absence of primer-dimer formation. Melting curve analysis showed that all 10 genes were giving specific amplification and there was absence of primer-dimer formation. Similar technical and biological precision in drought stress experiments leading to qRT-PCR testing of RGA gene was reported in Arabidopsis (Liu et al., 2007; Huang et al., 2008; Seo et al., 2009), soyabean (Stolf-Moreira et al., 2010) and maize ( $\mathrm{Li}$ and Wang, 2007; Xiao-feng et al., 2009).

The expression level of selected 10 RGA genes of french bean was measured in both resistant and susceptible genotype rust inoculated leaf tissues separately at 15 DAI and 45 DAI. All the 10 genes at 30 DAI and except COHFBRGA2 at 15 DAI were upregulated in resistant genotype. COHFBRGA1, COHFBRGA2, COHFBRGA25, COHFBRGA9 and COHFBRGA38 were down-regulated in susceptible genotype at 15 and 30 DAI. Whereas, COHFBRGA4, COHFBRGA9 and COHFBRGA27 (15 DAI) and COHFBRGA9 at 30 DAI showed up-regulation. COHFBRGA3 up-regulated at 30 DAI but expressed inversely at 15 DAI in susceptible genotype. Similarly, there was inverse trend in the expression status of COHFBRGA4 and COHFBRGA27. There was down-regulation of these genes at 30 DAI and were upregulated at 15 DAI. But COHFBRGA26 was down-regulated in susceptible genotype at 15 DAI and did not express at 30 DAI (Table 2).

RGA genes up-regulating and downregulating in leaf tissues of both resistant and susceptible genotypes at 15 DAI and 30DAI in pathogen challenged conditions is illustrated in Figure 1. At 15 DAI, in case of pathogen challenged leaf of resistant genotypes, the 9 COHFBRGA genes
(COHFBRGA1 to COHFBRGA38 except COHFBRGA2) were up-regulated with a fold change range of 0.79 to 169.01 and COHFBRGA2 was down regulated with a fold change of 0.79 . Whereas, at $30 \mathrm{DAI}$ in the resistant genotype, all RGA genes were up-regulated with a fold change range of 20.01 (COHFBRGA9) to 115.69 (COHFBRGA25). In case of susceptible genotype, 5 RGA genes with the fold change ranged between 1.59 and 11.10 (15 DAI) and 7 RGA genes with 0.10 (COHFBRGA38) to 19.29 (COHFBRGA9) were down-regulated. Highest fold expression was found at 15 DAI in resistance genotype by COHFBRGA26 and lowest noticed in susceptible genotype at 30 DAI by COHFBRGA38 (Figure 1).

Emediato et al., (2013) revealed that, gene expression for RGAs in both compatible and incompatible interactions across the infection time course with Mycosphaerella musicola in banana showed low levels of RGA expression in the early infection stages and up-regulation in late stages.

In contrast, other RGAs displayed high expression levels in the resistant cultivar during the early infection stage, strong downregulation in the intermediate infection stage, and recovery to higher levels in the final stages of the infection time course. Wang et al., (2006) reported that differences in transcript levels could be correlated with the reaction to susceptibility/resistance of the host plant to pathogen. Gao et al., (2006) found that some RGAs were expressed only after challenge with Verticillium dahlia in cotton.

In conclusion, this study strongly suggests that in common bean Assessing expression of RGAs in other tissues apart from leaf tissue at two time points to gain deeper understanding of these genes in manifestation of other disease. 


\section{References}

Anonymous.2015. Statistical data on horticulture crops in Karnataka state. Department of Horticulture. Government of Karnataka. Lalbagh. Bangalore.

Arumuganatham, K. And Earle, E. D.1991. Nuclear DNA content of some important plant species. Plant. Mol. Boil. Rept., 9: 208-218.

Buchanan, C. D., Lim, S., Salzman, R. A., Kagiampakis, I., Morishige, D. T., Weers, B. D., Klein, R. R., Pratt, L. H., Cordonnier-Pratt, M. M., Klein, P. E. And Mullet, J. E.. 2005. Sorghum bicolor transcriptome response to dehydration, high salinity and ABA. Pl. Mol. Bio., 58: 699-720.

Chini, V., Foka, A., Dimitracopoulos, G. And Spiliopoulou. 2007. Absolute and relative real time PCR in the quantitation of tst gene expression among methicillin resistant Staphylococcus aureus: Evaluation by two mathematical models. Soc. App. Microbiol., 45: 479-484.

Claus, A. L., Jens, J. L. And Torben, O. F. 2004. Normalization of real-time quantitative reverse transcription-PCR data: A model-based variance estimation approach to identify genes suited for normalization, applied to bladder and colon cancer data sets. Cancer Res., 64: 5245-5250.

Coyne, D. P. And Schuster, M. L. 1975. Genetic and breeding strategy for resistance to rust (Uromyces phaseoli Reben Wint.) in beans (Phaseolus vulgaris L.). Euphytica, 24: 795-803.

Czechowski, T., Bari, R. P., Stitt, M., Scheible, W. R. And Udvardi, M. K. 2004. Real time PCR profiling of over 1400 Arabidopsis transcription factors: unprecedented sensitivity reveals novel root and shoot specific genes. Pl. J., 38: 366-379.

Emediato, F. L., Passos, M. A. N., Teixeira, D. C. C., Pappas, G. J. And Miller, R. N. G. 2013. Analysis of Expression of NBS LRR resistance gene analogs in Musa acuminata during compatible and incompatible interactions with Mycosphaerella musicola. Acta Hort., 986: 255-258.

Flor, H. H. 1956. The complementary genic system in flax and fax rust. $A d v$. Genet., 8: 29-54.

Gao, Y. L., Guo, W. Z., Wang, L. And Zhang, T. Z. 2006. Isolation and characterization of resistance and defense gene analogs in cotton (Gossypium barbadense L.). Life Sci., 49:530-542.

Harter, L. L. And Zaumeyer, W. J. 1941. Differentiation of physiological races of Uromyces phaseoli typica on bean. J. Agric. Res, 62: 717-731.

Huang, D., Wu, W., ABRAMS, S., R. And Cutler, A., J. 2008. The relationship of drought related gene expression in Arabidopsis thaliana to hormonal and environmental factors. J. Exp. Bot., 59(11): 2991-3007.

Kakar, K., Wandrey, M., Czechowski, T., Gaertner, T., Scheible, W. R., Stitt, S., Torres-JEREZ, I., Xiao, X., Redman, J. C., Wu, H. C., Cheung, F., Town, C. D. And Udvardi, M. K. 2008. A community resource for high throughput quantitative RT PCR analysis of transcription factor gene expression in Medicago truncatula. Pl. Meth, 4: 18-23.

Kalpan., 1981. What is the origin of the common bean? Econ. Bot., 35: 240254.

Li, H. Y. And Wang, T. Y. 2007. Isolation and characterization of induced genes under drought stress at the flowering stage in maize. DNA Seq., 18(6): 445460. 
Liebenberg, M. M. And Pretorius, Z. A.2010. Common Bean Rust: Pathology and Control. Horticultural Reviews, 37: 174.

Liu, C., Zhou, J., Bracha-Drori, K., Yalovsky, S., Ito, T. And YU, H. 2007. Specification of Arabidopsis floral meristem identity by repression of flowering time genes. Develop., 134: 1901-1910.

Livak, K. J. And Schmittgen, T. D. 2001. Analysis of relative gene expression data using real time quantitative PCR and the 2-DDCT method. Pl. Meth., 25: 402-408.

Lopez, C. E., Acosta, I. F., Jara, C., Pedraza, F., Gaitan-Solis, E., Gallego, G., Beebe, S. And Tohme, J. 2003. Identifying resistance gene analogs associated with resistance to different pathogens in common bean. Phytopathol., 93: 88-95.

Mackay, I. M., Arden, K. E. And Nitsche, A. 2002. Real time PCR in virology. Nucl. Acids Res., 30: 1292-1305.

Marino, H. J., Cook, P. And Miller, K. S.2003. Accurate and statistically verified quantification of relative mRNA abundances using SYBR Green I and realtime RT-PCR. $J$. Immunol. Meth., 283: 291-306.

Mohan, N., Aghora, T. S., AND Girija, G.1993. Sources of resistance to rust (Uromyces phaseoli) in french bean. In: Golden Jubilee Symposium Horticultural Research changing Scenario, May 24-28, 1993. Bangalore, Karnataka, India.

Prajapati, N. D.2003. A hand book of medicinal plants: A complete source book. Agrobios. Jhodhpur. 538, 539 and 390.

Ramakers, C., Ruitjer, J. M., Deprez, R. H. And Moorman, A. F.2003. Assumption free analysis of quantitative real time polymerase chain reaction (PCR) data. Neurosci. Let., 13: 62-66.

Rangaswamy, G.1975. Diseases of Crop Pants in India (2nd edn.), Prentice Hall of India Pvt., Ltd., New Delhi, pp. 250.

Ruth, C., Martin, V. G., Hollenbeck, T., James, E. And Dombrowski, G., 2008, Evaluation of reference genes for quantitative RT-PCR in Lolium perenne. Crop Sci., 48: 1881- 1887.

Seo, P. J., Xiang, F., Qiao, M., Park, J. Y., Lee, Y. N., Kim, S. G., Lee, Y. H., Park, W. J. And Park, C. M., 2009, The MYB96 transcription factor mediates abscisic acid signaling during drought stress response in Arabidopsis. Pl. Physiol., 151: 275289.

Stolf-Moreira, R., Lemos, E. G. M., CararetoAlves, L., Marcondes, J., Pereira, S. S., Rolla, A. A. P., Pereira, R. M., Neumaier, N., Binneck, E., Abdelnoor, R. V., Oliveira, M. C. N., Marcelino, F. C., Farias, J. R. B. And Nepomuceno, A. L.2010. Transcriptional profiles of roots of different soybean genotypes subjected to drought stress. Pl. Mol. Bio. Rep., 56: 234-241.

Wang, X., El Hadrami, A., Adam, L. R. And Daayf, F.2006. Local and distal gene expression of pr-1 and PR-5 in potato leaves inoculated with isolates from the old (US-1) and the new (US-8) genotypes of Phytophthora infestans (Mont.). Environ. Exp. Bot., 57:70-79.

Xiao-Feng, D., Feng-Ling, F. And Wan-Chen, L, I. 2009 Differential gene expression in response to drought stress in maize seedling. Agril. Sci., 8(7): 767- 776.

Yang, S. S., Valdés-López, O., Xu, W. W., Bucciarelli1, B., Gronwald, J. W., Hernández G. And Vancel, C. P.2010. Transcript profiling of common bean 
(Phaseolus vulgaris L.) using the gene chip soybean genome array: Optimizing analysis by masking biased probes. BMC Pl. Biol., 10: 158.CALDANA, C., SCHEIBLE, W. R., MUELLER-ROEBER, B. AND RUZICIC, S., 2007, A quantitative RT PCR platform for high-throughput expression profiling of 2500 rice transcription factors. Pl. Meth., 3: 1746-1748.

Yu, A., Geng, H. And Zhou, X.2006. Quantify single nucleotide polymorphism (SNP) ratio in pooled DNA based on normalized fluorescence real time PCR. $B M C$ Genom., 7: 143-153.

\section{How to cite this article:}

Divya, B., B. Fakrudin and Devappa, V. 2019. Expression Profiling of Resistance Gene Analogs from French Bean (Phaseolus vulgaris L.) for the Manifestation of Rust (Uromyces phaseoli L.). Int.J.Curr.Microbiol.App.Sci. 8(03): 1760-1773.

doi: https://doi.org/10.20546/ijcmas.2019.803.206 